\title{
MENGGAGAS FIKIH TASAMUH DI TENGAH MASYARAKAT MULTIKULTURAL
}

Ridwan ${ }^{*}$

\begin{abstract}
An accommodative Islamic law is needed in this multicultural society. Ijtibad is an inner dynamic which guides the changes. Fiqh as the reflection of ulama responds the pluralism towards the problems in the society.
\end{abstract}

Kata kunci: multikultural, pluralisme, tasämụ

\section{A. Pendahuluan}

Hubungan antar umat beragama, khususnya dalam masyarakat yang majemuk selalu diwarnai oleh pasang surut, baik dalam skala lokal, nasional maupun internasional. Meskipun doktrin setiap ajaran agama mengajarkan keharmonisan, kedamaian, kerukunan, saling menghormati, saling menjunjung, namun dalam realitas sosialnya, hubungan antar umat beragama tidak selamanya harmonis. Kenyataan membuktikkan bahwa doktrin agama, fatwa ulama, keputusan konsili atau kesepakatan dewan gereja, belum menjamin terlaksananya idialitas doktrin tersebut. Berbagai kepentingan politik, ekonomi, sosial maupun budaya ikut mewarnai pergumulan, dinamika pasang surutnya hubungan antar umat beragama. Di sinilah lahirnya kesenjangan

- Penulis adalah Magister Hukum Islam dan Dosen tetap Jurusan Syariah STAIN Purwokerto. Sekarang sedang menempuh Program Doktor Konsentrasi Hukum Islam UIN Syarif Hidayatullah Jakarta. 
antara das sollen dan das sein, antara yang seharusnya dengan kenyataanya. ${ }^{1}$

Agama seharusnya dipahami sekaligus dibangun di atas pandangan dan komitmen kebersamaan yang menitikberatkan pada nilai spiritualitas dan aktualitas. Spiritualitas dan aktualitas di sini bukan sekedar bagaimana menampilkan agma dalam bentuk-bentuk ritual yang verbal, melainkan bagaimana agama itu mengejawantah ke dalam pribadi dan sosial masyarakat beragama secara menyeluruh. Artinya bisa tampil nyata dalam kehidupan keseharian manusia yang mampu berbicara sendiri pada umatnya tanpa rekayasa protektif yang bersifat artificial dan membosankan.

Ketika agama hanya dipahami dalam bingkai formalisme semata dengan hanya mengedepankan kulit atau cangkang saja, maka agama akan mudah dilihat oleh orang lain sebagai saingan. ${ }^{2}$ Oleh karena itu, perlu pola pemahaman agama secara holistikkomprehensif sehingga mampu menangkap pesan dasar agama sebagai rahmat alam semesta dan mampu mengemas pesan itu untuk kemudian dirancang dan diformulasikan secara tepat untuk mendialogkannya secara damai.

Melalui kerangka pemahaman seperti ini didukung kesadaran kolektif setiap insan beragama untuk membumikannya maka pelembagaan konsep tasāmub (toleran) dan kesediaan untuk mengerti dan memahami serta menerima keragaman (qabül aläkhar) akan mudah terwujud dalam pengembangan proyek kolaborasi antara ummat beragama atas nama kemanusiaan dengan semangat religiusitas untuk menyelesaikan persoalan kemanusiaan. Kalau agama mampu memerankan peran strategis demikian maka kehadiran agama menjadi sumber kedamaian

${ }^{1}$ Alef Theria Wasim (eds), Harmoni Kebidupan Beragama: Problem, Praktik \& Pendidikan (Yogyakarta: Oasis Publisher, 2005). hal. 36.

${ }^{2}$ H.M. Ridwan Lubis, Cetak Biru Peran Agama: Merajut Kerukunan, Kesetaraan Gender dan Demokratisasi dalam Masyarakat Multikultural, Jakarta: Puslitbang Kehidupan Beragama, 2005), hal.73. 
bukan sumber konflik. Kebutuhan akan perlunya membangun kerangka pemahamanan keagamaan yang toleran menjadi sangat mendesak ketika kita dihadapkan pada realitas bangsa yang multikultur. Pemaknaan agama dalam realitasnya lebih dipahami sebagai aturan yang hanya berdimensi hukum saja atau fikih. Oleh karena itu membangun sikap toleran atas keragaman agama akan efektif jika cara pandang fikihnya kondusif bagi penciptaan iklim kehidupan yang toleran.

\section{B. Konsep dan Teori Multikultural}

Multikulturalisme secara sederhana dapat dipahami sebagai pengakuan, bahwa sebuah negara atau masyarakat adalah beragam atau mejemuk. Sebaliknya, tidak ada satu negara pun yang hanya mempunyai kebudayaan nasional tunggal. Oleh karena itu multikulturalisme merupakan sunnatullah yang tidak bisa ditolak oleh bangsa manapun. Pandangan dunia multikulturalisme dipandang sebagai titik tolak dan fondasi bagi kewarganegaraan yang berkeadaban. Di sini, multikulturalisme dapat dipandang sebagai landasan budaya (cultural basis) tidak hanya bagi kewargaan dan kewarganegaraan, tetapi juga bagi pendidikan. $^{3}$

Konsep multikulturalisme menjadi isu aktual dan diperbincangan secara massif baru mulai pada paruh abad ke-20 yang lalu. Diskursus multikulturalisme lahir berpangkal dari perjuangan hak asasi manusia (civil right movement) yang melibatkan sejumlah pendidik dan para ahli guna menyediakan basis bagi kepemimpinan multikultural. ${ }^{4}$ Istilah Multikulralisme secara etimologis terdiri dari dua kata yaitu "multi" yang berarti plural dan "kulturalisme" yaitu kultur dan budaya. Istilah plural mengandung arti berjenis-jenis, karena pluralisme bukan berarti

3 Azyumardi Azra, "Pendidikan Agama: Membangun Multikulturalisme Indonesia" Kata Pengantar buku, Zakiyuddin Baidhawy, Pendidikan Agama Bervawasan Multikultural (Jakarta: Erlangga, 2005), hal. vi.

${ }^{4}$ H.M. Ridwan Lubis, Cetak Biru Peran Agama,. hal. 112-113. 
sekedar pengakuan akan adanya hal-hal yang berjenis-jenis tetapi juga pengakuan tersebut mempunyai implikasi-implikasi politis, sosial dan ekonomi. Oleh karena itu konsep pluralisme sangat terkait erat dengan konsep demokrasi. Pluralisme juga berkenaan dengan hak hidup kelompok masyarakat yang ada didalam suatu komunitas yang didalamnya hidup budaya yang beragam. ${ }^{5}$

Konsep Multikulturalisme dengan pluralisme adalah dua hal yang tidak dipisahkan. Multikulturalisme secara leksikal mengandaikan adanya pluralitas kultural dalam sebuah komunitas. Kultur mempunyai dua karakter dasar. Pertama, kultur adalah sesuatu yang bersifat general sekaligus spesifik. General berarti bahwa setiap manusia di dunia ini mempunyai kultur, dan spesifik berarti setiap kultur pada sekelompok masyarakat adalah bervariasi antara satu dengan lainya. Kedua, kultur adalah sesuatu yang bisa dipelajari. Ketiga, kultur adalah sebuah simbol baik yang bersifat verbal maupun non verbal. Keempat, kultur dapat membentuk dan melengkapi sesuatu yang alami. Kelima, kultur adalah sesuatu yang dilakukan secara bersama-sama yang menjadi atribut bagi invidu sebagaianggota dari kelompok masyarakat. Keenam, kultur adalah sebuah model. Artinya kultur bukanlah kumpulan adat istiadat atau keyakinan semata yang tidak artinya sama sekali tetapi ada seperangkat nilai dibalik kultur itu. Ketujuh, kultur adalah sesuatu yang bersifat adaptif dalam proses kehidupan dengan berbagai dinamikanya.

Kultur sebagai sebuah konsep sosial, secara kategoris peta wilayahnya tebagi menjadi tiga, yaitu kultur nasional, internasional, dan sub-sub kultur. Kultur nasional berisi aneka macam pengalaman, sifat dan nilai yang berbentuk aneka macam pengalaman, sifat dan nilai-nilai yang dipakai oleh semua warga negara yang berada dalam satu negara. Kultur internasional adalah bentuk-bentuk dari tradisi kultural yang meluas melampaui batasbatas wilayah nasional sebuah negara melalui proses penyebaran

${ }^{5}$ H.A.R. Tilaar, Multitulturalisme: Tantangan-tantangan Global Masa Depan dalam Transformasi Pendidikan Nasional, (Jakarta: Grasindo, 2004), hal. 82. 
(diffusion) yaitu sebuah proses penggabungan antara dua kultur atau lebih melalui berbagai cara seperti perkawinan, migarsi ataupun media massa. Adapun sub kultur adalah perbedaan karakteristik kultural dalam sebuah kelompok masyarakat. Di Indonesia misalnya sub kultur atas dasar etnis kita melihat ada budaya Jawa, Sunda, Madura, Padang, Bugis dan sebagainya. Dalam Islam, misalnya ada sub kultur Sunni ataupun Syi'i. ${ }^{6}$

Studi sosiologi dan antropologi tentang masyarakat majemuk (plural society) selalu menggambarkan bahwa multikulturalisme merupakan "idiologi" dari sebuah masyarakat multikultural yaitu masyarakat yang tersusun oleh keragaman etnik. Ada beberapa definisi multikulturalisme sebagaimana ditulis oleh Alo Liliweri yaitu: ${ }^{7}$

Pertama, multikulturalisme adalah sebuah konsep yang menjelaskan dua perbedaan dengan makna yang saling berkaitan; (1) Multikulturalisme sebagai suatu kemajemukan budaya atau pluralisme budaya daris suatu masyarakat. Kondisi ini diasumsikan akan membentuk sikap toleransi, (2) Multikulturalisme merupakan seperangkat kebijakan pemerintah pusat yang dirancang sedemikian rupa agar seluruh masyarakat dapat memberikan perhatian kepada kebudayaan semua kelompok etnik atau suku bangsa.

Kedua, multkulturalisme merupakan konsep sosial yang diintroduksi ke dalam pemerintahan untuk dijadikan sebagai dasar kebijkaan. Hal ini didasarkan pada argumentasi bahwa hanya pemerintah yang dianggap representatif ditempatkan di atas kepentingan maupun praktik budaya semua kelompok etnik dari suatu bangsa. Diharapkan setiap kebijakan pemerintah mampu mendorong lahirnya sikap apresiatif, toleran, perasaan setara di antara seluruh komponen masyarakat bangsa.

\footnotetext{
${ }^{6} \mathrm{M}$. Ainul Yakin, Pendidikan Multikultural: Cross-Cultural Understanding untuk Demokrasi dan Keadilan (Yogyakarta: Pilar Media, 2005), hal. 6-12.

${ }^{7}$ Alo Liliweri, Prasanglea \& Konflik: Komunikasi Lintas Budaya Masyarakat Multikultur (Yogyakarta: LKiS, 2005), hal. 68-69.
} 
Ketiga, jika dikaitkan dengan pendidikan multikultural (multicultural education), multikulturalisme merupakan strategi pendidikan yang memanfaatkan keragaman latarbelakang kebudayaan dari para peserta didik sebagai salah satu kekuatan untuk membentuk sikap multikultural. Startegi ini sangat bermanfaat untuk membangun pemahaman bersama atas konsep kebudyaaan, perbedaan budaya, keseimbangan, dan demokrasi dalam artian luas.

Keempat, multikulturalisme sebagai sebuah idiologi dapat dikatakan sebagai gagasan bertukar pengetahuan dan keyakinan yang dilakukan melalui pertukaran kebudayaan atau perilaku budaya setiap hari. Melalui idiologi multikulturalisme itulah, masyarakat diajak untuk menerima standar umum kebudayaan yang dapat membimbing kehidupan dalam sebuah masyarakat yang majemuk.

\section{Dinamika Pemikiran Hukum Islam}

Sebuah ketentuan hukum pada hakikatnya merupakan respon dan artikulasi kebutuhan sosial. Secara teoritik, kemunculan suatu hukum dalam sebuah masyarakat didasarkan pada asumsi bahwa masyarakat dalam melakukan interaksi ataupun transaksi sosial memerlukan suatu perangkat yang bersifat normative sebagai acuan norma yang secara sosial disepakati bersama. Pada posisi ini, hukum berfungsi sebagai mekanisme untuk mengendalikan sosial (mechanism of sosial control) ${ }^{8}$ dan mengatur masyarakat juga sekaligus sebagai instrumen untuk rekayasa sosial (sosial engineering).

Dalam Islam, ketentuan-ketentuan hukum yang tertuang dalam al-Qur'an pada umumnya turun dilatar belakangi oleh sebab-sebab tertentu yang dalam ilmu tafsir disebut asbäb an-nuzū termasuk di antaranya adalah ayat tentang hukum waris. Oleh karena itu untuk memahami ketentuan nas al-Qur'an tidak boleh

${ }^{8}$ Soerjono Soekanto, Pokok-Pokok Sosiologi Hukum, (Jakarta: Rajawali Press, 2003), hal. 69. 
mengabaikan dimensi historisitas yaitu mempertimbangkan pada setting sosial apa, di mana dan kapan ayat tersebut diturunkan/ diundangkan. Menurut Fazlur Rahman, sebagaimana dikutip oleh Jalaluddin Rahmat, untuk bisa memahami ayat al-Qur'an secara tepat kita harus mengetahui aspek historis (asbāb an-nuzūil) dan background sosiologisnya.

Islam sebagai perangkat agama kehadiranya di dunia adalah untuk merealisir cita-cita kemaslahatan manusia yang pada tataran implementasinya tergambar dari ketentuan-ketentuan yuridis-normatif baik dalam al-Qur'an maupun al-Hadits yang dasar pijaknya adalah nilai persamaan, keadilan dan kemerdekaan. Syari'at Islam merupakan konsep ajaran agama yang mengatur seluruh dimensi kehidupan umat manusia. Dengan demikian syari'at Islam merupakan konsep kehidupan yang komprehensif. ${ }^{10}$

Namun demikian, ketentuan-ketentuan hukum baik dalam al-Qur'an maupun al-Hadits sebagian besar dinyatakan dalam bentuk bahasa yang umum (mujmal) sehingga memerlukan ijtihad. ${ }^{11}$ Oleh karena itu sangat memungkinkan atau bahkan suatu keniscayaan akan lahirnya keragaman interpretasi atas teks-teks keagamaan. Lahirnya ragam interpretasi di kalangan umat Islam menurut al-Qordhawi, sebagaimana dikutip oleh Huzaimah Tahido Yanggo, disebabkan oleh tiga faktor utama. Pertama, tabiat agama Islam sendiri yang dasar normatif-tekstualnya sangat terbuka untuk kemungkinan lahirnya berbagai interpretasi. Dengan kata lain ragamnya interpretasi karena al-Qur'an dan alHadits sendiri memberi peluang untuk itu. Kedua, tabiat manusia

'Jalaluddin Rahmat, "Tinjauan Kritis atas Sejarah Fikih: dari Fikih al-Khulafa' alRasyidin Hingga Mazhab Liberalisme," dalam Budhy Munawwar Rachman (ed.), Kontekstualisasi Doktrin Islam dalam Sejarab, (Jakarta: Paramadina, 1995), hal. 300.

${ }^{10}$ A. Zaki Yamani, al-Shari'ab al-Khälidah wa Mushkilät al-'Asrr, alih bahasa Mahyuddin Syaff, (Bandung: PT Al-Ma'arif, 1986), hal. 34-35. Lihat pula, Hasbi Ash-Shiddiqy, Falsafab Hukum Islam, (Jakarta: Bulan Bintang, 1993), hal. 179-180. Bandingkan pula A.E Priyono, Islam Piliban Peradaban, (Bandung: Shalahudin Press, 1984), hal. 72.

${ }^{11}$ Ibn Rushd, Bidāal al-Mujtahid wa Nibāyah al-Muqtasid, (Indonesia: Dār al-Ihyā'a alMaktabah, t.t.)., hal. 2

Al-Manāhij, Vol. 3 No. 2, Juli - Desember 2009 
yaitu bahwa setiap manusia (termasuk mujtahid/mufassir) mempunyai berbagai interes dan perbedaan perspektif dalam memahami bahasa teks dan realitas konteks sosial yang melingkupinya. Ketiga, tabiat bahasa yang merupakan produk budaya, maka struktur bahasa agama (Arab) sudah barang tentu memungkinkan untuk ditafsirkan secara beragam misalnya karena mempunyai banyak makna (mushtarak) atau maknanya masih umum ('ámm) atau sebaliknya maknanya khusus (khāṣs). ${ }^{12}$

Ketiga faktor tersebut, kalau kita tarik dalam bingkai pembumian ajaran agama berarti perlunya mempertimbangkan aspek-aspek lokal (local wisdom) di mana hukum Islam tersebut akan di bumikan. Akomodasi hukum Islam atas tata nilai lokal yang ragam dalam entitas masyarakat yang multikultur diperlukaan agar apapun produk hukum yang dihasilkan tidak tercerabut dari akar budaya lokal dan masyarakat mengganggap bahwa hukum tersebut adalah bagian dari cita-cita keadilan yang hidup dan berkembang di tengah masyarakat. Oleh karena itu watak fikih pasti dinamis, partikular dan lokal-temporal (dibatasi ruang dan waktu). Konsep ruang dan waktu adalah konsep kebudayaan yang menjadi bagian khas dari fikih yang merupakan refleksi religius seorang ulama dalam merespon masalah hukum di sekitar lingkungan sosialnya. Oleh karena itulah watak dasar fikih sesungguhnya pluralis. Pluralisme hukum Islam (fikih) disebabkan karena rancang bangun keilmuannya (dimensi epistemologis, ontologis dan aksiologisnya) memang terbuka untuk lahirnya pluralitas

Masyarakat dengan berbagai dinamika yang ada menuntut adanya perubahan sosial, dan setiap perubahan sosial pada umumnya meniscayakan adanya perubahan sistem nilai dan hukum. Marx Weber dan Emile Durkheim menyatakan bahwa "hukum merupakan refleksi dari solidaritas yang ada dalam masyarakat”. Senada dengan Marx Weber dan Durkheim, Arnold

12 Huzaemah Tahido Yanggo, Pengantar Perbandingan Mazbab, Jakarta: Logos Publishing, 1993), hal. 64-65. 
M. Rose mengemukakan teori umum tentang perubahan sosial hubungannya dengan perubahan hukum. Menurutnya, perubahan hukum itu akan dipengaruhi oleh tiga faktor; pertama, adanya komulasi progresif dari penemuan-penemuan di bidang teknologi, kedua, adanya kontak atau konflik antar kehidupan masyarakat, dan ketiga, adanya gerakan sosial (sosial movement) ${ }^{13}$. Menurut teori-teori di atas, jelaslah bahwa hukum lebih merupakan akibat dari pada faktor-faktor penyebab terjadinya perubahan sosial.

Pengaruh-pengaruh unsur perubahan di atas dapat menimbulkan perubahan-perubahan sosial dalam sistem pemikiran Islam, termasuk di dalamnya pembaruan hukum Islam. Pada dasarnya pembaruan pemikiran hukum Islam hanya mengangkat aspek lokalitas dan temporalitas ajaran Islam, tanpa mengabaikan aspek universalitas dan keabadian hukum Islam itu sendiri. Tanpa adanya upaya pembaruan hukum Islam akan menimbulkan kesulitan-kesulitan dalam memasyarakatkan hukum Islam khususnya dan ajaran Islam pada umumnya. ${ }^{14}$

Untuk mengawal hukum Islam tetap dinamis, responsif dan punya adaptabilitas yang tinggi terhadap tuntutan perubahan, adalah dengan cara menghidupkan dan menggairahkan kembali semangat berijtihad di kalangan umat Islam. Pada posisi ini ijtihad merupakan inner dynamic bagi lahirnya perubahan untuk mengawal cita-cita universalitas Islam sebagai system ajaran yang salị̣ li kulli zamān wa makān. Ibn Rusyd menyatakan dalam kitabnya Bidāyah al-Mujtabid, bahwa sumber-sumber hukum normatif-tekstual sangatlah terbatas jumlahnya, sementara kasus-kasus baru di bidang hukum tidak terbatas jumlahnya. ${ }^{15}$. Dengan demikian Ijtihad merupakan satu-satunya jalan untuk mendinamisir ajaran Islam sesuai dengan tuntutan perubahan zaman dengan berbagai

${ }^{13}$ Soerjono Soekanto, Pokok-Pokok., hal. 96. Bandingkan pula dengan, Astrid S. Soesanto, Pengantar Sosiologi dan Perubaban Sosial, (Jakarta: Binacipta, 1985), hal. 157-158.

${ }^{14}$ Muhammad Azhar, Fikih Kontemporer Dalam Pandangan Neomodernisme Islam, (Jogjakarta: Pustaka Pelajar,1996), hal. 59-60.

${ }^{15}$ Ibn Rusyd, Bidäyat al-Mujtabid., hal. 2. 
konpleksitas persoalanya yang memasuki seluruh dimensi kehidupan manusia.

Landasan normatif ijtihad sebagai metodologi istinbät hukum dalam rangka dinamisasi ajaran agama, adalah dialog Rasulullah dengan sahabat Muadz Ibn Jabal yang menyatakan bahwa ia akan melakukan ijtihad bila tidak mendapatkan ketentuan hukum dalam al-Qur'an dan Hadits dari suatu kasus hukum. Tidak terdapatnya penjelasan hukum dalam al-Qur'an dan al-Hadits, menurut Amir Syarifudin dapat di lihat dari dua segi: ${ }^{16}$

1. Al-Qur'an dan al-Hadits secara jelas dan langsung tidak menetapkannya, tidak secara keseluruhan dan tidak pula sebagiannya. Contoh pada kasus ini adalah gerakan kodifikasi al-Qur'an dalam satu mushaf.

2. Secara jelas, al-Qur'an dan al-Hadits memang tidak menyinggung hukum suatu kasus, namun secara tidak langsung atau bagiannya ada penjelasannya. Contoh hukum memukul kepala orang tua tidak ada aturan secara eksplisit dalam alQur'an, tetapi ada larangan mengucapkan kata-kata kasar (uff) terhadap orang tua. Hukum memindahkan organ tubuh orang mati kepada orang yang masih hidup (tranplantasi) tidak ada ketentuan nasnya yang secara spesifik merujuk pada hal itu, namun ada larangan merusak jasad orang mati. Karena tidak jelas dan tidak langsungnya penjelasan al-Qur'an dan al-Hadits, maka diperlukan upaya ijtihad.

Sementara itu, menurut Muhammad Musa al-Tiwana, sebagaimana dikutip oleh Asafri Jaya Bakri, obyek ijtihad itu dapat di bagi menjadi tiga bagian; pertama, ijtihad dalam rangka memberi penjelasan dan penafsiran terhadap nas, kedua, ijtihad dalam melakukan qiyas terhadap hukum-hukum yang telah ada dan telah disepakati, ketiga, ijtihad dalam arti penggunaan ra'yu. Pandangan al-Tiwana tersebut mengacu pada dua pemeliharaan

${ }^{16}$ Amir Syarifudin, Ilmu Usbul Fikib 2, (Jakarta: Logos,1999), hal. 287. 
objek ijtihad yang luas. Pertama, adalah persoalan-persoalan yang sudah ada ketentuan nasnya, namun masih bersifat zanni (dugaan). Terhadap objek yang seperti ini, cara yang ditempuh adalah penelitian dalam menentukan makna al-ämm (umum) atau al-khäṣs (khusus), al-mutlaq (mutlak) dan al-muqayyad (makna yang dibatasi). Kedua, persoalan-persoalan yang sama sekali belum ada nasnya. Pada hal yang semacam ini, maka pemecahannya dilakukan melalui ijtihad dengan menggunakan qiyas, istihsan dan dalil-dalil hukum lainnya ${ }^{17}$.

Bertitik tolak dari objek ijtihad di atas, ada dua corak penalaran yang perlu dikemukakan dalam upaya menggali maqāsid al-shari'ah. Dua corak penalaran dalam berijtihad tersebut adalah;

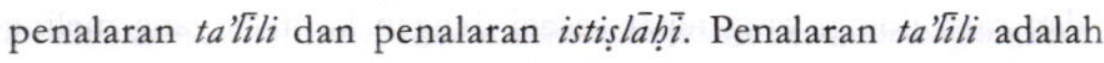
upaya penggalian hukum yang bertumpu pada penentuan illatillat hukum yang terdapat dalam suatu nas. Asumsi dasar dari penalaran ini adalah bahwa nas-nas dalam masalah hukum sebagian diiringi dengan penyebutan illatnya. Dalam kajian usul fikih, corak ta'tili ini mewujud dalam bentuk qiyās dan istiḅsān. Adapun penalaran istișlậ̣ $\bar{i}$ adalah upaya penggalian hukum yang bertumpu pada prinsip-prinsip kemaslahatan yang disimpulkan diri nas. ${ }^{18}$

Kedua model penalaran di atas adalah bertumpu pada penggunaan al-ra'yu. Oleh karen itu terdapat tiga karakter yang melekat dalam dua pendekatan di atas. Pertama, pendekatan ini mencoba memahami ketentuan nas tanpa terikat secara kaku dengan bunyi teks dan mengalihkan perhatiannya pada upaya mencari semangat moral yang terkandung dalam nas. Kedua, upaya mengganti pendekatan ta'abbudi kepada pendekatan ta'aqquli. Ketiga, upaya merumuskan 'illat hukum dan pesan moral nas dengan melihat setting sosial dan konteks zamannya. Dalam kaitan dengan dinamika masyarakat yang selalu berubah diiringi

${ }^{17}$ Asafri Jaya Bakri, Konsep Maqbasbid Syari'ah Menurut as-Syatibi Jakarta: Rajawali Press, 1996), hal. 100.

${ }^{18}$ Ibid., hal. 132-133. 
dengan munculnya masalah yang kompleks, maka dua corak/ pendekatan penalaran di atas tampak lebih responsif dan solutif dalam menjawab masalah hukum. Tawaran teoritik dua pendekatan ini adalah kerja ilmiah melalui deduksi analogis dengan dasar pijakannya kemaslahatan.

Islam meyakini perubahan sebagai suatu realitas yang tidak bisa diingkari. Islam juga memberi posisi yang paling tepat demi memudahkan semua hal untuk berubah secara shahih dan aman. Agama berjalan bersama beriringan dengan lajunya kehidupan. Tugas agama adalah mengawal perubahan secara benar untuk kemaslahatan hidup manusia. ${ }^{19} \mathrm{Di}$ sinilah sesungguhnya tugas seorang cendekiawan muslim untuk merumuskan pendekatan dan metodologi yang tepat sesuai dengan konteks yang melingkupinya agar agama menjadi fungsional dan bisa membumi. Dalam hukum Islam, perubahan sosial budaya dan letak geografis menjadi variabel penting yang ikut mempengaruhi adanya perubahan hukum. Ibnu Qayyim al-Jauziyah menyatakan, bahwa "perubahan fatwa adalah dikarenakan perubahan zaman, tempat, keadaan dan kebiasaan" 20 . Dalam kaidah fikih lainnya disebutkan "hukum itu berputar bersama illatnya (alasan hukum) dalam mewujudkan dan meniadakan hukum"21.

Kaidah fikih di atas memberikan landasan bagi pengembangan hukum Islam dengan wawasan multikultural. Variabel waktu (time), tempat (space), dan tradisi (culture) merupakan tiga factor pembentuk hukum yang bertumpu pada dimensi historisitas yang berwatak dinamis. Lahirnya berbagai mazhab hukum (fikih) dalam rentang sejarah pemikiran hukum Islam dengan corak dan watak yang berbeda-beda membuktikan watak

\footnotetext{
${ }^{19}$ Abdul Halim Uways, Fikib Statis Dinamis, (Bandung: Pustaka Hidayah, 1998), hal. 221.

${ }^{20}$ Ibn Qayyim al-Jauziyah, I'lam al-Muawaqi'in 'an Rabbi al-'Alamin, (Bairut: Daar al-Fikr, tt), hlm. 14. Lihat pula, Hasbi ash-Shiddiqie, Falsafab Hukum Islam., hal. 444.

${ }^{21}$ Mukhtar Yahya dan Fathurrahman, Dasar-Dasar Pembinaan Hukum Fikib Islam, (Bandung: PT Al-Ma'arif, 1996), hal.550.
} 
fikih yang dinamis dan selalu beradaptasi dengan pluralitas budaya lokal di mana pemikiran hukum itu lahir.

Salah satu bukti konkrit betapa faktor lingkungan sosial budaya berpengaruh terhadap hukum Islam adalah munculnya dua pendapat Imam Syafi'i yang dikenal dengan qawl al-qadim dan qawl al-jadid. Pendapat lama (qawl al-qadim) adalah pendapat hukum Imam Syafi'i ketika beliau berada di Mesir, sedangkan qawl aljadid ketika beliu tinggal di Baghdad. ${ }^{22}$. Perbedaan pendapat hukum dalam masalah yang sama dari seorang Mujtahid Imam Syafi'i jelas disebabkan faktor struktur sosial, budaya, letak geografis yang berada antara daerah Iraq (Baghdad) dan Mesir.

Dalam konteks historis, pemikiran bidang hukum Islam sesungguhnya memperlihatkan kekuatan yang dinamis dan kreatif dalam mengantisipasi setiap perubahan dan persoalanpersoalan baru. Hal ini dapat di lihat dari munculnya sejumlah mazhab hukum yang memiliki corak sendiri-sendiri sesuai dengan latar belakang sisio-kultural dan politik dimana mazhab itu tumbuh dan berkembang. Warisan monumental yang sampai sekarang masih memperlihatkan akurasi dan relevansinya adalah kerangka metodologi penggalian hukum yang mereka ciptakan. Dengan perangkat metodologi tersebut, segala permasalahan bisa didekati dan dicari legalitas hukumnya dengan metode qiyas, maṣlaḥah al-mursalah, istị̣sān, istị̣ḥa a dan 'urf. ${ }^{23}$ Dalam posisi

\footnotetext{
${ }^{22}$ M. Atho' Muzdhar, Membaca Gelombang Ijtibad antara Tradisi dan Liberasi, (Jogjakarta: Titian Ilahi Press, 1998), hal. 107.

${ }^{23}$ Syamsul Arifin dkk., Spiritualisasi Islam dan Peradaban Masa Depan,Jogjakarta: Sipress, 1996), hal. 72-73. Adapun penjelasan perangkat metodologi Ijtihad/istinbät di atas adalah sebagai berikut. Qiyas adalah menyamakan suatu peristiwa hukum yang tidak ada nasnya dengan peristiwa hukum yang terdapat nas yang mengaturnya karena adanya persamaan 'illah (sebab) hukum antara keduanya. Maslabah mursalab adalah suatu kemaslahatan yang terlepas ayaitu kemaslahatan yang oleh agama tidak diperintah tetapi juga tidak dilarang/ditolak. Istibsān adalah berpalingnya seorang mujtahid dari qiyas jaly ke qiyas khafi atau berpalingnya seorang mujtahid dari hukum kulli ke hukum juz i. Istişbāb mengukuhkan atau menganggap tetap berlaku hukum yang pernah ada sampai diperoleh dalil lain yang mengubahnya. Urf/'Adat adalah apa-apa yang dibiasakan atau diikuti oleh orang banyak dan dilakukan berulang-ulang serta diterima baik oleh akal mereka.
} 
demikian, hukum Islam akan berfungsi sebagai rekayasa sosial (sosial engineering) untuk melakukan perubahan dalam masyarakat.

Untuk menempatkan hukum pada posisi yang betul-betul fungsional dalam menghadapi setiap perubahan sosial, diperlukan terobosan metodologis disertai kemampuan membaca fenomena zaman. Banyak perangkat ilmu bantu yang bisa menopang perumusan hukum menjadi aplikatif, seperti ilmu-ilmu tafsir, tarikh dan ilmu tata bahasa arab. Diharapkan melalui pendekatan konvergensi antara ilmu usul fikih dan ilmu-ilmu lainnya akan dapat mengurangi formalisme hukum Islam.

Dalam konteks ini, pemaknaan hukum Islam tidak harus dilihat dari perspektif nilai saja, tetapi perlu di cari keterkaitan secara organik dan struktural dalam kehidupan sosial. Di sinilah letak pentingnya fenomena transformasi pemikiran hukum Islam, tidak hanya dilihat sebagai fenomena keagamaan saja. Transformasi pemikiran hukum Islam di Indonesia merupakan suatu pergumulan kreatif antara Islam dengan masyarakat Indonesia, antara nilai-nilai Islam dengan kenyataan struktural masyarakat. Oleh karena itu, maka program pembaruan pemikiran hukum Islam adalah suatu bagian yang tidak terpisahkan dari proses kehidupan masyarakat yang selalu berubah.

Akan tetapi, untuk melakukan upaya pembaruan pemikiran hukum Islam (fikih) diperlukan beberapa syarat; pertama, adanya tingkat pendidikan yang tinggi dan keterbukaan dari masyarakat muslim, kedua, hukum Islam (fikih) harus dipandang sebagai variasi suatu keragaman yang bersifat partikular yang selalu dibatasi oleh dimensi ruang dan waktu, ketiga, memahami faktor sosio-kultural dan setting politik yang melatarbelakangi lahirnya suatu produk hukum agar dapat memahami partikularisme dari pemikiran hukum tersebut, keempat, mengorientasikan istinbat hukum dari aspek qaulan (materi hukum) kepada aspek manhajan (kerangka metodologis). Di samping itu, perlu juga memahami pemikiran hukum yang tidak dibatasi sekatsekat mazhab. 


\section{Menggagas Fikih Tasāmuḅ}

Dalam kaitan dengan bagaimana membangun hubungan antar umat beragama terdapat gagasan menarik dari Milad Hanna tentang perlunya budaya/fikih "menerima yang lain ( $q a b \bar{u} l$ al$\bar{a} k$ har). Hal ini penting untuk dikembangkan karena adanya kecenderungan untuk membenturkan satu agama, ras atau suku yang satu dengan yang lainya sehingga lahir sikap kebencian dengan "pihak lain". Tesis Samuel Huntington, "clash of civilization" dinilai sebagai provokasi yang justeru memperlebar jurang pemisah antara satu agama dengan lainya. Milad Hanna mengajukan dua resep guna melihat kembali hakikat kemanusiaan. ${ }^{24}$

Pertama, perlunya internalisasi nilai yang membawa semangat keragaman, kebersamaan, dan kesamaan identitas.Di sini perlunya penggalian khazanah, nilai-nilai dan moralitas dari masing-masing agama untuk kemudian dijadikan salah satu komitmen untuk membentuk masyarakat yang saling menghargai dan menghormati.

Kedua, perlunya undang-undang dan kebijakan structural yang dapat memayungi pluralisme. Disini diperlukan lembaga legislative, organisasi keagamaan dan kemasyarakatan, lembaga pendidikan yang senantiasa mendorong undang-undang yang dapat mewadahi gagasan pluralisme. Sebagai gerakan kultural, kelompok-kelompok masyarakat sipil diharapkan dapat berperan lebih besar untuk memberdayakan kelompok-kelompok minoritas dalam berpartisipasi mendorong proses transformasi sosial.

Wawasan multikulturalisme dalam konteks pluralisme agama menuntut adanya keterlibatan aktif dengan kaum agama lain, dalam arti bukan sekedar toleransi, melainkan memahami. Toleransi tidak perlu keterlibatan aktif dengan kaum lain. Toleransi tidak meredakan sikap acuh tak acuh sesama kaum beragama. Dalam dunia di mana perbedaan agama secara histories

${ }^{24}$ Mun'im A. Sirry (ed), Fikih Lintas Agama: Membangun Masyarakat Inklusif-Pluralis Jakarta: Paramadina, 2004), hal. 183-284. 
dimanpulasi untuk menghancurkan jembatan penghubung antar komunitas, pengetahuan dan pemahaman terhadap perbedaan agama hanya bisa dicapai jika kita mampu memasuki ruang dialog terbuka satu sama lain, tanpa takut menghadapi ketidaksepakatan besar. Pencarian moral dan spiritual yang tulus akan pemahaman bersama dalam tradisi-tradisi agama partikular kita akan merambah jalan bagi terciptanya satu kesatuan masyarakat dengan cara pandang keberagamaan yang inklusif.

Agama dan modernisasi sejatinya bersinergi jika manusia menginginkan peningkatan hidupnya di masa depan. Agama seharusnya dipahami sekaligus dibangun di atas pandangan dan komitmen kebersamaan yang menitikberatkan pada nilai spiritualitas dan aktualitas. Spiritualitas dan aktualitas di sini bukan sekedar bagaimana menampilkan agma dalam bentuk-bentuk ritual yang verbal, melainkan bagaimana agama itu mengejawantah ke dalam pribadi dan sosial masyarakat beragama secara menyeluruh. Artinya agama bisa tampil nyata dalam kehidupan keseharian manusia yang mampu berbicara sendiri pada umatnya tanpa rekayasa protektif yang bersifat artifisial untuk mecari solusi bagi persoalan kehidupan.

Beragama dengan hanya mendasarkan pada formalisme ajarannya apalagi ditambah cara pandangnya yang hanya menggunakan satu perspektif akan melahirkan cara pandang beragama dengan 'kacamata kuda' yang cenderung intoleran dan mengedepankan truth claim yang mudah memberikan judgement terhadap kelompok lain yang berbeda dengan berbagai stigma yang cenderung mendiskriditkan atas nama kebenaran kelompok yang diyakininya dan menafikan kemungkinan kebenaran orang lain tanpa terlebih dahulu melakukan kritik epistemology terhadap pola penalaran yang digunakannya. Setiap hasil tafsiran atas teks kitab suci sifatnya bypothetical (spekulatif), sehingga sikap toleran adalah cara terbaik menghadapi keragaman tafsir dengan berpegang pada sikap agree in disagreement yaitu sikap penghormatan terhadap realitas keragaman. Relatifitas hasil penafsiran terhadap 
teks-teks keagamaan sangat jelas tergambar dari pernyataan khalifah Abu Bakar setelah beliu memberikan keputusan hukum dengan menyatakan: "Inilah pendapatku tentang pembagian waris Kalalah, jika benar maka datangnya dari Allah dan Rasul-Nya, dan jika salah maka itu datangnya dari saya." ${ }^{25}$

Ketika agama hanya dipahami dalam bingkai formalisme semata dengan hanya mengedepankan kulit atau cangkang saja, maka agama akan mudah dilihat oleh orang lain sebagai saingan. ${ }^{26}$ Oleh karena itu, perlu pola pemahaman agama secara holistikkomprhensif sehingga mampu menangkap pesan dasar agama sebagai rahmat alam semesta dan mampu mengemas pesan itu untuk kemudian dirancang formulasi yang tepat untuk mendialogkannya secara damai.

${ }^{25}$ Muhammad ibn Abi Sahl al-Sarakhsỉ, al-Mabasüt (Bairut: Dār al-Ma'rifah, 1406), VI: 84. lihat pula, Abū Hāmid al-Ghazāili, al-Mustasfä (Bairut: Dār al-Kutub al-Araby, 1413), II: 287. Bandingkan dengan, 'Afi ibn Muh\}ammad al-Ämidi, al-Iḥkām fí Ușül alA ḥkām, (Bairut: Dār al-Kutub al-'Arabi, 1404 H), hal. 44.

${ }^{26}$ H.M. Ridwan Lubis, Cetak Biru Peran Agama, hal. 73 . 


\section{DAFTAR PUSTAKA}

Al-Āmidi, 'Ali ibn Muhammad. Al-Iḥkām fí Ușül al-Aḅkäm. Bairut: Dār al-Kutub al-'Arabi, 1404 H.

Arifin, Syamsul, dkk. Spiritualisasi Islam dan Peradaban Masa Depan. Jogjakarta: Sipress, 1996.

Ash-Shiddiqie, Hasbi. Falsafah Hukum Islam. Jakarta: Bulan Bintang, 1993.

Azhar, Muhammad. Fikib Kontemporer Dalam Pandangan Neomodernisme Islam. Jogjakarta: Pustaka Pelajar,1996.

Azra, Azyumardi. "Pendidikan Agama: Membangun Multikulturalisme Indonesia," Kata Pengantar buku, Zakiyuddin Baidhawy, Pendidikan Agama Berwawasan Multikultural. Jakarta: Erlangga, 2005.

Bakri, Asafri Jaya. Konsep Maqhashid Syari'ab Menurut As-Syatibi. Jakarta: Rajawali Press, 1996.

Al-Ghazāî, Abū Ḥāmid. Al-Mustasfá . Bairut: Dār al-Kutub alArabi, 1413.

Ibn Rusyd, Bidāyah al-Mujtabid wa Nihāyab al-Muqtasid. Indonesia: Dār al-Iḥyā‘ al-Maktabah, t.t.

Al-Jawziyah, Ibn Qayyim. I'lam al-Muawaqi'in 'an Rabb al'Álamin. Bairut: Dar al-Fikr, t.t.

Liliweri, Alo. Prasangka \& Konflik: Komunikasi Lintas Budaya Masyarakat Multikultur. Yogyakarta: LKiS, 2005. 
Lubis, H.M. Ridwan. Cetak Biru Peran Agama: Merajut Kerukunan, Kesetaraan Gender dan Demokratisasi dalam Masyarakat Multikultural. Jakarta: Puslitbang Kehidupan Beragama, 2005.

Muzdhar, M. Atho'. Membaca Gelombang Ijtibad antara Tradisi dan Liberasi. Jogjakarta: Titian Ilahi Press, 1998.

Priyono, A.E. Islam Piliban Peradaban. Bandung: Shalahudin Press, 1984.

Rachman, Budhy Munawwar (ed.). Kontekstualisasi Doktrin Islam Dalam Sejarah. Jakarta: Paramadina, 1995.

Al-Sarakhsi, Muhammad ibn Abi Sahl. Al-Mabasüt, 6 juz. Bairut: Dār al-Ma'rifah, 1406 H.

Sirry, Mun'im A. (ed.). Fikib Lintas Agama: Membangun Masyarakat Inklusif-Pluralis. Jakarta: Paramadina, 2004.

Soekanto, Soerjono. Pokok-Pokok Sosiologi Hukum. Jakarta: Rajawali Press, 2003.

Soesanto, Astrid S. Pengantar Sosiologi dan Perubaban Sosial. Jakarta: Binacipta, 1985.

Syarifudin, Amir. Ilmu Ushul Figh 2. Jakarta: Logos,1999.

Tilaar, H.A.R. Multikulturalisme: Tantangan-tantangan Global Masa Depan dalam Transformasi Pendidikan Nasional. Jakarta: Grasindo, 2004.

Uways, Abdul Halim. Fikih Statis Dinamis. Bandung: Pustaka Hidayah, 1998. 
Ridwan

Wasim, Alef Theria (eds.). Harmoni Kebidupan Beragama: Problem, Praktik \& Pendidikan. Yogyakarta: Oasis Publisher, 2005.

Yahya, Mukhtar dan Fathurrahman. Dasar-Dasar Pembinaan Hukum Fikih Islam. Bandung: PT. Al-Ma'arif, 1996.

Yakin, M. Ainul. Pendidikan Multikultural: Cross-Cultural Understanding untuk Demokrasi dan Keadilan. Yogyakarta: Pilar Media, 2005.

Yamani, A. Zaki. Al-Sharì'ah al-Khälidab wa Mushkilät al-'Așr, terj. Mahyuddin Syaff. Bandung: PT. Al-Ma'arif, 1986.

Yanggo, Huzaemah Tahido. Pengantar Perbandingan Mazhab. Jakarta: Logos Publishing, 1993. 